\title{
LIZ MCLAUGHLIN
}

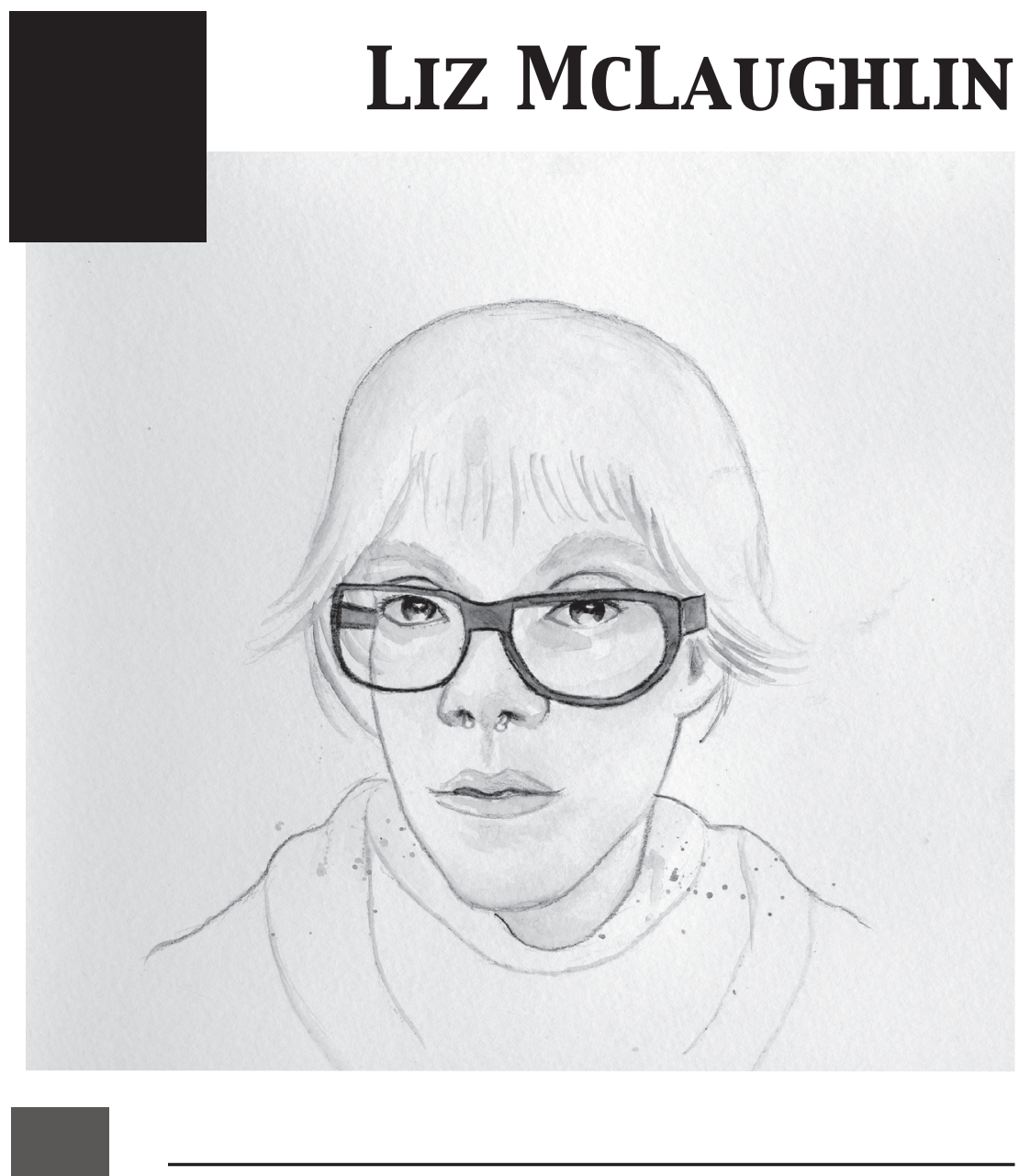

Liz McLaughlin is a writer of fictions and an eraser of poetry from Pittsburgh, PA, USA, Earth. She is a senior at the University of Pittsburgh who at one time must have thought it was a good idea to study Fiction Writing and English Literature simultaneously. Her passions include (but are not limited to) long narratives, flash fiction, urban cycling, grassfed beef, and one rep maxes. 


\section{THE ANGEL A'T THE TRESTLE}

The horror of what happened to Dayvon was not the catalyst.

Rather, my capacity to love changed: diminished at first and then transformed into something so huge and effuse I had to create a new emotion just to contain the joy and sorrow of it. My love for Marksomething that always had permanence-was etched away and replaced by this emotion so newly born and shaking I had to tattoo it onto my body like ink, like there was no way to remember it or read the message without breaking skin and digging down into flesh until blood welled up from beneath. The swelling growth of it stretched my heart muscle to tearing, exploded my tenderness into meaty bits of shrapnel so sharp and sudden I first laughed and then cried out from the pain of it - the sadness of something so imperfect, so essentially fucked as needing another person in such a way.

And after a while, the horror of it wasn't even horrible. It became obtuse, some mildly annoying thing - like doing dishes or fighting over who'd drive the first leg to Hilton Head or forgetting about daylight savings time and losing an hour of sleep when you have a double shift the next day. It was singular and solid, another normal event in the series of normal events that create life. Sometimes we talked about it. Often we cried or got drunk or clenched fists about it. Eventually we didn't acknowledge it at all.

However, one thing was certain: we didn't go to the tracks anymore.

It was August. Dayvon, Mark, and I, the great triumvirate.

When we weren't working, we would fill our backpacks with beer and ride our bikes to the river to lounge on the parked barges that had long ago merged with the shore. We would bake in the summer sun and gulp cans of frothy beer that grew warmer with each passing hour, while we grew less and less concerned with the flavor or the pleasure- 
we cared only about the maintenance of the fizz in our heads. One day Dayvon suggested we tie a rope swing to the branch of the strongest oak - the only tree to force its way up and out of the belly of the rusted barge - and so we did. The rest of the month, we took turns climbing to the top of the riverbank just to swing back down again. Just to feel the soaring of our bodies when we let go, to feel the impact - at times as hard as cement - when we hit the water, our feet finding purchase on the silty bottom of the riverbed.

\section{$* * *$}

In early September, the nights got cool and the excitement of the barges and the river and the rope swing waned. The previous winter Mark and Dayvon had started writing - just little tags here and there, throw ups in a runny hand with paint markers on fences and garbage cans, hours spent perfecting tags drawn on stickers with glossy ink. Over the summer, Dayvon started to really get up and began to carry cans of Krylon in his bag, little baggies of fat caps and flare tips. He was forging an identity in spray paint and stencils. He told his story on cement walls and overpasses, the paint running like sweat down the backs of ragged brick buildings, crouching on shaking haunches under shadowy bridges.

He started going bigger. We met at the rail yard, not the river, took turns spotting. A spent September air replaced the yeasty August nights. We weaved in and out and up and around those huge boxcars, climbed the ladders, and sat on top of them. The sound of tossed empty cans echoing our laughter, nights filled with the familiar crunching of gray gravel underfoot.

We had no way to know the trains were tributaries. Arteries that pumped blood away from our hearts. If their beating ceased, our hollows would become cold and empty, the liquid siphoned outward. We didn't realize the tracks led to an ever-hungering, black, and bloodthirsty night.

Dayvon's wake was on a Saturday. I spent the afternoon in the basement of the funeral home with Mark, pouring single digit ounces of coffee into tiny paper cups. 
Mark drank his coffee black. Dayvon drank his coffee black. All of the men in my life drank their coffee black. Dayvon had got me into it the winter prior. We'd go down to the all-night diner in the wee hours when twilight hands itself to morning and order slices of pie and bottomless ceramic mugs of coffee. Crusty caramelized pecan, sweet cinnamon apple, creamy pumpkin, sour cherry, foamy lemon meringue. The diner coffee at such an early or such a late hour was dark and thin, hot water dressed in a coffee suit. Dayvon said it was his favorite kind of coffee, much better than the thick-bodied oily sludge everyone loves from cafes. This coffee tastes like the earth, he said. Tastes like dirt, he said, and all things come from the dirt. I nodded. Having some bitter in your life makes the sweets even sweeter.

\section{I had agreed.}

Standing at the refreshment table surrounded by the mourning, I poured a steady two-count column of sugar into my coffee and did not stir it.

I handed Mark a paper cup and sat down. He brought the steaming liquid to his face and frowned into it.

"The coffee is weak."

I shifted my eyes from my black slacked thighs to him. That morning we had begun the construction of a wall bricked solely of obvious statements. We had four solid corners of sentiment built up to about waist deep. We had either forgotten how to talk or simply didn't know what to say. It wasn't uncomfortable though — just more quiet. We were almost entirely bricked in.

"But it's hot and that's nice," he added.

I stared down at my hands. They were foreign: skin white like paper, too vascular.

"Yes," I replied into my cup, into my palms, into the carpet. 
I could sense the pleading largeness of his eyes without having to look into his face. I excused myself to use the restroom.

I sat on the toilet in the basement of the funeral home, surrounded by so much gray and beige and quiet. The fluorescent light a steady buzz I felt throughout my body. My slacks gathered taught at the bend of my knees. I leaned my cold arms into the white of my legs, cut the bones of my elbows into the muscles of my thighs.

I was unmistakably alive.

I voided my bladder and was somehow less empty after, the continued function of my body an affront to the cease and desist letter of my mind. I loosened my grip on the wadded ball of tissue in my hand, unfurled it, and smoothed it on my leg. I expected to see the wide loop of his tag or the cramping scrawl blueprint of a new throw up or any one of his characters sketched in blood or ink or paint. I expected something surprising or something foreboding written on the tissue or the palms of my hands or the slate gray of the bathroom stall, but there were only pleats, wrinkled palms, smooth paint —a vast and empty lightness. I folded myself in half, a hard crease down the center, and coughed a dry sob into my knees.

When I went back to the lounge, Mark was standing against the wall holding my coffee. He handed it to me and said, "Let's get out of here."

I looked straight and solid into his eyes for the first time since the night we heard the news about Dayvon. I drank down my last ounce of coffee. It was cool and thick and sweet and stuck to the back of my teeth like the first letter of his name. Like the words depression and damaged and disaster and deceased.

Mark took me by the hand and led me up the stairs - past what was left of Dayvon, past that whispery room with the closed box like a door 
that can never be opened again, past the unintroduced family, the history we didn't know, the stories we will never be told - right into the blinding white happiness of that early fall day. The glaring blue skies an insolent pronouncement that light always transcends the dark.

Mark and I walked in silence to his place. The October air sang. We reached the building and climbed the stairs to the second story apartment. Before I could even shrug off my jacket he grabbed me by the arms, put his mouth on my mouth. We hadn't touched in days and the effect of flesh gripping flesh startled me. I did not want to make love or have sex or be fucked, but it had been so many hours, so many days since I had been inside my body. I could see the passion pulse through him - his hands and his mouth and all of the places a human body can press energy - but I felt nothing. He pawed at me out of some desire perhaps to consume me, but his sweetness and anger and frustration and lust just beaded on my hard outer layer and rolled off me into a puddle on the floor underneath us.

I couldn't feel his softness or skin or the smoothness of his bodyonly his hardness: a grid, his framework, the skeleton construction of him. His body simply bones and blood and meat. I wasn't a body any longer - not flesh and bone, but the hollow spaces in between.

Mark worked to quiet his hurting on top of me. On the pile of our faded black clothes. In the pooling of his emotion as it seeped into the hardwood floors. On the foundation the house was built upon, above the soil of the earth just miles away from where we would secrete Dayvon, where

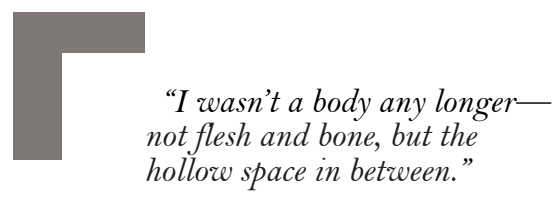
he would slip into the dirt to sleep in the cold darkness of the
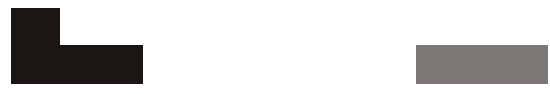
underground. I floated just above this all, just above us both, and marveled at the leanness of my being.

One week after we tipped him back into the earth, I started finding it hard to sleep. And I'd lie there and my swinging mind always settled on 
one specific night in October.

That October night opened her door like you open your windows on those fall evenings where the wind is warm and smooth on your skin and you know she is going to close it with the same slamming ferocity you do the next morning when you realize winter had arrived while you slept.

Mark had to work late that night. Dayvon called me around eightthirty and told me to meet him at the train trestle on the south side of the city. He said he had something to show me. I pulled on my sneakers and threw a few cans of beer into my backpack with a hooded sweatshirt and a hat in case it got cold. I grabbed my black book and a few markers. I had started tracing letters in fat graffiti slang, drawing obtuse characterscartoon representations of who I thought we were or who I thought we could be. I hadn't birthed a moniker, couldn't lift my identity off paper. I couldn't settle on something so permanent, a single word or phrase or vision to represent me. The world seemed so vast and effortless that without constraints my mind ran like the trains, crisscrossing across the country, traveling seamlessly from one state to another-I felt like everywhere at once and nowhere at all and I couldn't comprehend how a person could pick just one thing to define themselves wholly. So I brought the sketchpad everywhere I went, kept mining for that single word to define me, that one word to introduce myself to the world.

When I got to the trestle, I leaned my bike against the expanded steel steps and set my bag on the sidewalk. I was fumbling with the mechanism of my chain lock under the orange glow of the sodium-vapor lamps when Dayvon spooked me. He was standing on the sidewalk and I turned and caught him out of the corner of my eye. He was standing there stiff and straight, with a grave look on his face.

I said something like Hey Day or Jesus Christ! or What's up?-I don't remember now. It seemed unimportant at the time and probably still is. Now I wonder only because I'm trying to figure out why the mind places emphasis on such things. I remember how tall he was- he was always tall, but this night he was standing so straight—like a soldier at 
attention.

He stayed silent while I locked my bike and picked my bag up off the sidewalk and pulled out two cans of beer and turned to face him.

I didn't need hindsight to recall the expression on his face.

Surely I frowned at him and asked what was wrong and in response he shook his head and smiled a small smile. A flitting flash of a thing I could catch between my thumb and forefinger, fold, stuff into that pointless fifth pocket in a pair of jeans if I had the foresight to do such a thing — but I didn't.

Every seemingly purposeless thing has its place.

When I offered him a beer, he only mumbled something about needing to be sober, about it fuzzing his head, which seemed kind of unlike him but what did I know. I tossed his can back into my bag and popped the tab on mine, tilted it to my lips, let the bubbling warm foaminess coat my tongue.

Dayvon then spoke the name he reserved only for me-let it sing in the air for a moment between us. And then he added, Come here, I want to show you something.

He turned and walked under the trestle to the tracks and I followed. As my eyes adjusted to the lack of light, I realized he had rolled the entire cement abutment supporting the trestle bridge above-blanked the canvas completely, covered all the other tags and hollows and simples. The piece was so large to see it all at once I had to cross to the far side of the tracks. The entire thing used at least five colors - must have taken two crates of paint. It was the fucking Sistine Chapel of the Southside.

It wasn't his usual wildstyle but the letters of the burner popped right off the cement. The 3D was incredible. I started to say, Day, when the fuck did you get so-, but then I read the piece. It was a straight, easy to make out the letters. I had been so taken aback by the layout 
and execution, I didn't notice at first what it said, that it wasn't what he usually wrote.

Outlined in flat white, filled with banner red, highlighted in satin black, true blue, bauhaus gold, the piece exploded into life from the cement.

This is you? I pointed to the piece. When did you-

His face resurrected. I ain't that person anymore. I just-I can't.

We spent the rest of the evening sitting on the trestle, talking. He told me about the past few months, the darkness. How he couldn't figure out what to do with his hands. He poured it all out to me-let it splash off the trestle and onto the tracks.

I asked him if he'd used and he paused before responding but said no. He said No, no, no, but it seems so inevitable. He said, I didn't know. He said, It's just so goddamn hard.

I said, I'll always be here. I wasn't lying.

We picked apart the hows and whys and wheres and whens. We spent the night alternating between words and long silences, between sitting apart and sitting beside one another, pressing our hands together and pressing our faces against the diamond wire fencing of the trestle. From on the trestle above the tracks we watched the growing white globes, the light of trains as they chugged toward us. We waited for the build.

We spoke, but in stunned anticipation of every single train that passed because it gave us a reason to be silent, to get caught up in the pulsing steel song of the surging tracks just feet below us. The power and speed - the urgency and momentum of locomotion - the swallowing and effort and building and climax spinning in the air all around us. The trestle quaking with the resonance of it, our knees knobby and shaking, the air vibrating in our lungs and making it hard to breathe. We were 
on fire with it. We watched every train as it came down upon us and we turned around and watched each train decrescendo out of our sight and sound and senses. We watched the train leave the tracks and waited for the return of the quiet, to fill the air with great clouds of words - our guts and fears and dreams and hopes and histories. When all of our words had been spoken and the atmosphere of the trestle had been filled to overflowing, we simply waited again for another train to come to carry them away. Our conversations pulled out of our mouths, out of us, out into the night, out into the city in the slipstream of the escaping trains.

I became overwhelmed with his honesty-the transparency of his words - the immensity that he had shared this all with me.

But he didn't share why he told me. Or why he brought me to the trestle.

He didn't say why he changed his name. Or tell me how he went through the entire city and dissed every one his old tags — even the little ones scribbled on bus stop signs and newspaper boxes. He didn't let me know he ghosted all his old pieces, so when Mark and I went to find them only their shadows remained. He didn't explain why he buffed himself from the scene or why he splashed a can of paint over the very first burner he got props for or why he rolled over the whole-car we scouted just a month prior.

He certainly didn't tell me how bad it really was.

Or that he had lost all hope.

Or how when he showed me his last piece he felt christenedabsolved-forgiven of all future sin.

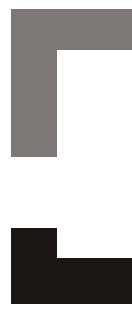

"He certainly didn't tell me how bad it really was.

Or that he had lost all hope."

Or that he was just trying out a way to say goodbye. 
The conductor said he just stepped onto the tracks.

When the engine was about five-hundred feet out - just walked onto the tracks and turned forty-five degrees to face the barreling bullet of metal hurtling westward, bathed in the growing light of the headlamp, the screaming of brakes that physically could not create enough friction.

The coroner said he had no traces of any drugs, alcohol, illicit substances in his system. He was in the best of health, considering.

The police said really when this happens it is such a tragic thing. The community is saddened by this loss and we are so very sorry-we want to apologize to the people who had to find what was left of the body.

The undertaker said there is simply not a way we can hold an open casket. And don't you really think it's better to remember him the way he was then, the way he was the last time you saw him?

In the months that followed, our relationship changed. Mark held onto me tighter and with quiet desperation. I maintained our friendship in an attempt to feel anything that might remotely resemble emotion.

Winter had settled into Mark's apartment and with the closing of the windows, the interior space became unbearable. He wanted nothing more than to spend every moment wrapped within us and I wanted nothing more than to jump out of my skin, or the window, or both.

I began staying at my apartment more often and leaving his place without telling him where I was going or when I planned to return. In the beginning, he questioned me, berated me, argued with me. Eventually he gave up and let me go. I always returned.

Sometimes I would go to the bar on the corner, sip vodka tonics 
and watched the patrons come and go. After a while I bored of staying in one place and started to explore random places throughout the city. Dive bars and jazz clubs and sports pubs and kitschy college taverns. I loved the potential - the different types of people who haunted each venue, the swell of possibility, a chance encounter, the changing atmosphere.

One night I sat in a dusty saloon that proclaimed Thursday to be jazz night. I listened to the sad coughing of a baritone sax and worked on my third glass of house red. The woman sitting on the stool next to me offered a cigarette. I didn't smoke, but what the hell did I have to lose, so I took one. When she lit it for me, I got a look at her face and something clicked inside me. I asked her name.

"Ellie." She lit hers right after mine without extinguishing the flame.

I don't know what it was about her.

It might have been the hint of a half-smile, or the dark brown almondshaped eyes, or the square jawline. It might have been the sober sadness mixed with the rejuvenation of sloughing off one's sins. It might have been the wine or that first drag of nicotine or the graffiti I stared at on the train over or that her skin was the exact color of the diner coffee we used to drink. After a few more jazz sets and cigarettes, another glass of wine for me and two fingers of whiskey for her, after some knocking of knees, a few throaty laughs, the way she smiled with her tongue between her teeth, the was or why ceased to matter. I pinned her to the wall in the woman's restroom and tucked my fingers behind her belt and my pressed my lips to her lips and breathed her in and felt fucking alive again.

\section{$* * *$}

I built momentum, became unstoppable. After so long living in shades of gray and black and white, I exploded in color. She reminded me of Dayvon and yet she wasn't at all like him. It was like connecting with him all over again, but not him-someone with just enough of him to be his sister-it was as if I could do it all over, do it right this time. I could live tangential to him. 
I began going to see her more often, spending more and more time with her, until Mark asked where I had been.

Until she started to ask where I had to always be getting and couldn't I just stay with her a few nights a week.

I was walking the tracks between two worlds that seemed incapable of existing without each other and yet I seemed incapable of choosing one side of the tracks over the other. So I ignored them both and put it out of my mind until I couldn’t any longer.

I left the apartment one afternoon while Mark was at work and rode my bike to the trestle. He had written me a letter that morning, pleading with me to let him in, to let him help, to let him do anything. He proclaimed his love for me. She had left several voicemails asking me where I'd been and why I wasn't answering and hoping I was alright and dammit just get back to me already before I start calling the hospitals.

It was early January - that time of the year when everything is bright and crisp and frozen, but not so far removed to be the barren deadness of winter. The sun was low but brilliant, the sky an impossible blue. Everything etched with the spidery softness of white frost; the roads veined with salt, the trees outlined in snow.

I hadn't been to the trestle since that night in October, but when I got there, nothing permanent had changed. The cement and expanded metal and steel beams and rivets and fencing of the scene declared indestruction. At the end of time, when all was lost, only cities would be left. The skeletons of the monoliths we create.

Dayvon's burner had not gone untouched. New tags cropped up on the edges and at the bottom - the easy places to reach. A three-color piece obscured the first letter. His burner was so huge and so sprawling it invited people to cover it. Something that large creates a clean canvas for others. Graf artists would have left his piece alone for longer perhaps, if 
they knew who wrote it, since he had started getting up around the city. But Dayvon had never gone by this name, except for this piece-he never had a chance to get up under this identity. No one knew who it was. No one knew this was Dayvon - the kid who had fallen. That kid who stepped in front of the train.

I reached in my bag and pulled out a can of satin white. I shook the paint and listened to the ball bearing clang around, trapped inside the can. I stuffed the paint into the front pocket of my hooded sweatshirt and climbed the sloping cement of the abutment supporting the trestle. When I got to the top, I had to crawl across the steel rafters under the trestleshimmy across the expanse, wedged between the cement lip and the steel grid above - to get to right above the center of his piece.

I was terrified of the height, even though it was only maybe fifteen feet. I was terrified of where I'd been the previous four months, of what the future held - terrified to move forward and think backward. But I was not afraid to do what needed to be done.

I edged across the cement using all four of my limbs, crouching like a crab. When I reached the middle of the trestle, I hooked my fingers around the lip of the steel beam and relaxed the rest of my body. The rubber toes of my sneakers applied traction to the cement wall and I was able to release my right hand. I pulled the satin white from my pocket and gave the ball bearing a few cracks for good measure. I began to spray. I painted as far as my arm could reach and then shimmied over to continue the curving sweep. I connected the lines each time, crawling with a curving grace, until I had painted a white halo over the entirety of Dayvon's name, until I had made him an angel.

I worked my way back down to the ground and crossed the tracks to see the piece as a whole. The fresh paint was stark and obvious next to the newer tags and Dayvon's piece, which was already beginning to fade into the cement. We can mark this city up as much as we want, but our names are not permanent. Time washes our bones clean.

I heard the metallic singing of a train far down the tracks and placed 
my fingers on the cold silver metal to feel the vibrations tingle through my skin. Looking eastward, I could just make out the almost imperceptible glowing star of an engine as it barreled down the tributary-toward the city - toward the hollow where my heart used to be. 